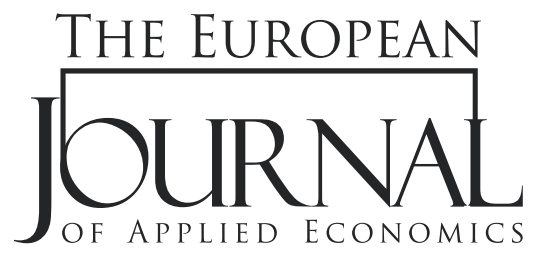

\title{
THE IMPACT OF CERTAIN PSYCHOLOGICAL FACTORS OF INVESTORS AND MANAGERS ON THE CAPITAL STRUCTURE
}

\author{
Mirko Babanić \\ PhD candidate, Singidunum University, \\ Belgrade, Serbia
}

\begin{abstract}
:
Psychology represents the basic requirement for the emergence of disciplines such as behavioral finance and behavioral economics. It has contributed to a better understanding of the behavior of economic actors under conditions of risk arising from the imperfections of cognitive abilities of human beings. Consequently, it is necessary to change the economic models based on mathematical laws in favor of descriptive models that consider the cognitive abilities of the human mind. The most common decisions that are being studied in the field of behavioral finance are the decisions regarding capital structure in companies. The methodology in this paper is based on the net operating income approach. This approach is analyzing the financial section of income statement that refers to the financial expenses of the companies. Financial expenses are assumed to be fixed, determining financial break even, as a consequence of use of financial leverage. The main task of this paper is to determine the impact of some psychological factors in the terms of capital structure and financial leverage, through two case studies of comparative analysis of income statements of the companies Puma and Adidas that will consequently affect the achievement of financial breakevens well as the profitability of the companies. Therefore it is possible to conclude that some analyzed psychological aspects in the process of financial decision making of investors and managers can influence the capital structure decisions, which can be a subject of further researches.
\end{abstract}

\section{Article info:}

Received: November 9, 2017

Correction: January 22, 2018

Accepted: January 22, 2018

\section{INTRODUCTION}

According to Baker and Ricciardi (2013) scientific areas such as behavioral finance and behavioral economics did not appear until the early 1990s of the 20th century in various scientific journals, and were primarily used by the professors of finance, and later on by investors and the broad reading audience. These authors further state that the foundations of behavioral finance and similar sub-subjects, such as the behavior of investors, can be traced back to events that were defined as speculative behavior during the so-called tulip mania crisis of the 17th century. Books that were written in the 19th and 20th century about investing psychology signed an initiation of theoretical foundations in modern theory of investor behavior.

\section{Keywords:}

Biases, personal beliefs, capital structure, financial leverage, beta coefficient 
American psychologist Daniel Kahneman and economist Vernon Lomax Smith, who were awarded Nobel Prize in Economics in 2002, confirmed the inevitability of psychology in the prediction and explanation of human behavior. Psychology thereby contributed to the creation of more realistic economic models and behavioral economy was then created, which mainly dealt with the fact that emotions and the structure of the mindset of people affected the process of economic decision-making. Namely, the economic models based on mathematical laws, from which inferences were made about the economic impact in making economic decisions, had to be replaced by descriptive models that would consider human imperfections due to the effect of incomplete information, emotions, context and the form in which the problem was defined. Also, an important aspect are categories such as experience, attitudes and beliefs of individuals, economic decision makers, not only of investors and company managers but also of consumers in general.

In the 1970s of the 20th century a cognitive psychology in the study of decision-making was established, which is a common approach in psychology, oriented towards the understanding and explanation of psychological processes. The dominant interest of cognitive psychology, as a new branch of psychology, are phenomena such as perceptions and the level of attention as well as the definition of concepts, information processing, memory, and problem solving. By developing prospect theory which undoubtedly started the analysis of decision making under the risk as a consequence of the aforementioned psychological phenomena, Kahneman and Twersky (1979) established the basis of behavioral economics. Hackbarth (2008) proves that economists are focused on models in which market participants behave rationally and have homogeneous expectations. Nevertheless, a great number of researches in psychology show that people are inclined to excessive optimism and overconfidence. This is actually the consequence of the fact that they believe they have more reliable knowledge of the future events than they actually do. The explanation of these attitudes is that there is a divergence in the beliefs between the managers and the market in relation to the value of the company. Namely, we can conclude that personal beliefs of managers make a heterogeneity between anyhow identical companies. Besley and Brigham (2015) explain this attitude by examples of pharmaceutical and biotechnology companies that do not use high amounts of debt, because their production is unpredictable, and therefore the large use of debt instruments is considered to be extremely inconsequential. Contrary to them, public utility companies use high amounts of debt, especially long-term debts, because their fixed assets and stable sales represent high-quality insurance for mortgage-backed securities. Besley and Brigham (2015) also cite examples from 2010 of companies like the Genetech, which had about 25\% of debt in capital structure, which was also the industry average, and GlaxoSmithKline, which had almost $80 \%$ of debt in its capital structure (see examples 1 and 2 in Chapter on Methodology), which leads to the conclusion that the managers' attitudes play a basic part in determining an aim of capital structure.

This paper will show that the following hypothesis applies:

H1: the company's capital structure change by increasing the level of its debt, caused by the influence of some psychological factors inherent of investors and managers, will always as a result have an increase of its systemic risk exposure measured by the beta coefficient.

This paper is organized in two global parts. The first part consists of a literature review, which covers the fields of the rationality of human behavior, investor behavior, investor psychology and the influence of some psychological constructs on decision-making process on capital structure. The second part introduces the methodology based on the approach of net operating income, which deals with the areas of derivation of the equations and independency of net operating income from capital structure, while at the end, the last topic under the title of account examples, shows the testing of the net profits over income statements (see Appendix) of companies such as Puma and Adidas (for 2014 and 2015 years). 


\section{LITERATURE REVIEW}

Economics as Mankiw (2008) argues that it is the science that deals with the study of human behavior, but it also deals with choices which people make in life. The basic premise of traditional economics is that people always behave rationally, similar to the attitude that company managers always make the maximum profit, or the consumers always get the maximum utility, or select a position on the highest indifference curve. Therefore, with all the restrictions, consumers measure all the incurred costs and benefits, and on this basis, select the best relation. However, real people are complex beings, and they are not always calculating individuals, which is the premise of the traditional economic theory. Herbert Simon, one of the first sociologists who were engaged in marginal issues of economics and psychology, suggested that people are not viewed as rational beings that maximize, but as beings who satisfy their needs (Mankiw, 2008). Thus, the research needs to go in the direction that people make decisions that are not always the best option, but are good enough. Some economists believe that people are just "approximately rational" and that attempts should be made in studying the human behavior and decision-making in order to identify systemic errors that they make. The most common errors include: excessive self-confidence, which manifests itself as an overestimation of their own opportunities; attributing extreme importance to a small number of striking observations, which occurs due to excessive confidence in someone's judgment; reluctance to change opinions or interpretation of evidence in a manner that it confirms existing beliefs (Mankiw, 2008).

The question which arises is why the economy is based on the assumption of rationality when it comes to everyday behavior. The answer may be that the assumption of rationality, if not fully, is at least approximately accurate. Namely, economic models are not imagined as a copy of reality, but should show the essence of specific problems, and help in its understanding (Mankiw, 2008). According to this, economists can be satisfied with the theory which is not perfect but is good enough. The further insight of human behavior can be illustrated by an experiment, which is known under the name of the ultimatum game. By conducting such experiments psychologists have come to the conclusion that people rely on their innate sense of justice, which can be particularly noticeable when analyzing the behavior of employees in connection with their wages, when for example, the company that they work for has made above average results, they will justifiably expect to be paid a fair share of award, even in cases that the equilibrium in the labor market does not support it. The subsequent insight in human behavior can be analyzed in connection with decisions about consumption and saving, which are an important example in which people eventually show inconsistency. Namely, most people have a desire for instant gratification than denial, thereby initiating the decision-maker to abandon his previous plans. Thus, the decision about saving requires sacrifice in the present in order to receive an award in the future. The general conclusion of the previously described may be that there is a ubiquitous imperfection, given that, the information and political system and people are not perfect, economists have to understand all these imperfections as precisely as possible if they want to explain or develop the world that surrounds them (Mankiw, 2008). Namely, the study of human behavior conducted in psychology and economics shows that the way people decide is more complex than assumed in traditional economic theory, where a conclusion was reached that people are not always rational.

Ackert (2014) argues that the traditional approach in the field of finance, which has been the dominant paradigm for a few decades, is characterized by the fact that investors make rational decisions, taking care of maximizing the expected utility. The main areas of traditional finance are portfolio theory, (see Markowitz, 1959), capital asset pricing model (see Sharpe, Alexander \& Bailey, 1995), the efficient market hypothesis, (see Fama, 1970). Ackert (2014) further says that the evidence shows that many 
of the assumptions and conclusions associated with traditional finance are invalid. On the contrary, researchers of behavioral finance turned towards observing behavior, in order to develop models that describe how investors really make decisions. Behavioral finance uses understanding of the social sciences, especially psychology, for a better understanding of investor behavior of both individuals and groups and the entire market. Altman (2014) argues that the behavioral economy approach in making decisions is based on the bounded rationality process of investors. This approach is compared to the errors and biases approach, for a better understanding of the decision-making process and obtaining results. The emphasis is placed on the value of cognitive illusions and biases considering the limited capacity of information processing which a human brain has. These two approaches try to create meaning and try to explain why the results of decision-making, as a rule, are inconsistent in relation to the predictions of traditional economics and, in particular, from the standpoint of the efficient market hypothesis, see (Fama, 1970).

Bogan (2014) argues that, when it comes to behavior in making decisions related to household investments, they are based on traditional financial models which are often not precise. Farrell (2014) argues that, when it comes to demographic and socio-economic factors in the behavior of investors, it is crucial to understand how they are choosing their portfolio. Existing working papers describe that men are more aggressive in investing than women, as well as white people compared to black investors. Mansour and Ilassi (2014) write about the impact of religion on financial and investment decisions. Religion actually has an enormous influence on people's lives and is closely linked to their economic conditions. Xiao (2014) writes about the issue of the relation of money and happiness. Money in this case represents factors associated with income, while happiness is usually measured as life satisfaction or life fulfillment. Researchers suggest that personal income is responsible for the increase of happiness. What's more, studies show that people who live in wealthy countries are happier and that there is an inverse causal relation that happier people create a higher income (Xiao, 2014).

Fisher (2014) argues that in accordance with the behavioral finance theory, investors are not rational participants, as described by the economic theory. A lot of evidence from studies of investment behavior indicates that they perform contrary to their best interests (Fisher, 2014). However, there exists, fortunately for the investors, an adviser institute which can help them to remain rational, regardless of how the market would behave in improving their odds to stay focused on long-term investment strategy and therefore realize their own benefit.

Kramer (2014) says that some aspects of people psychology induced by external factors such as the changes of the seasons play a very important role in making financial decisions of individuals with significant economic consequences, which are perceived even at the level of the entire market. Consequently, psychological explanations are necessary to clear up the real decision-making process, especially in cases where there are rumors that affect the mood of market participants and their behavior at the level of total financial market. All these aspects are often excluded from the scientific finance literature.

Ricciardi and Rice (2014) write that, when it comes to risk, there is a lot of scientific literature, which identify, describe and analyze risk. Behavioral finance includes subjective and objective risk factors, both in the field of risk observation and risk tolerance. The perception of risk is, according to these authors, a subjective process regarding assess of risk and the level of risk tolerance (Ricciardi \& Rice, 2014).

Considering the emotions and financial markets, Fairchild (2014) argues that the latest research in the field of behavioral finance recognizes, in contrast to traditional finance which are based on a model of rational choice and on the assumption that market participants are fully rational which maximize the expected utility, that in reality investors and managers are not fully rational, for the reason that they are affected by psychological biases and influenced by emotions when making decisions. 
Capital structure is the most significant issue in the corporate finance theory (Bilgehan, 2014). In accordance with the references in the field of finance, there are many approaches that define the theory of capital structure, of which the most important are, as Besley and Brigham (2015) argue, the trade off theory, created in 1958 by professors Modigliani and Miller, and the pecking order theory, which is a consequence of asymmetries in information. Modigliani and Miller assumed that investors have the same information about the business operations of companies as their managers, which is called the symmetry of information in the literature. However, managers who manage companies have much better information about their companies than external players, like investors, which creates a relationship known as information asymmetries. This relationship has a significant impact on decisions on the capital structure of companies. Namely, such relationship significantly influences whether debt or equity will be used to finance capital projects.

For this purpose, we will consider the different perceptions of managers regarding the business of their companies. As Besley and Brigham (2015) write, if managers perceive the growth in sales by introducing a new product for which new installations need to be built, the question arises as to how the new capital should be raised? The considerations of managers can be explained in the following way: if a company is issuing shares, when the profit from the new product begins to arrive, the price of the shares will grow very fast, and the buyers of new shares will make a fortune. Old shareholders, including managers, will also achieve good results, but not as good as if the company did not issue new shares before the rise of stock prices, as in that case old shareholders would not have to share benefits with new shareholders. Therefore, in the case described above, regarding the perception of managers regarding the favorable outlook for business operations of the company, one should expect the decision that the necessary additional capital is to be raised by debt issuance, which would change the capital structure in terms of the higher level of debt (see examples 1 and 2 in the Chapter on Methodology). However, since managers of a company keep projects on introducing new products a secret, in order to put off the entry of competitors on the market, the same is true for the managers of competing companies, which creates an impression for both sides, which Bilgehan (2014) and Hackbarth (2008) call biases, overconfidence and optimism, in achieving better results than the competition. Namely, the projection of future events can be based on incomplete or even incorrect information, which by themselves represent a risk and can lead to wrong decisions, which can further cause the bankruptcy of the company. Žigić and Hadžić (2012) say that risk assessment is a comprehensive analysis process in analyzing risk, because risk evaluation is very important in the decision-making process regarding capital structure of companies, where experts in companies determine potential losses with the likelihood of their occurrence. It can be considered in the following way: what will happen if the market does not accept the new product of a company at all, which is not a rare case, or if the competition enters the market with its own new product before it is presumed. In this case, companies can endure serious losses, which are caused by the irrational behavior of managers, which, in the literature of behavioral finance, as referred to above, is called overconfidence and optimism. The previously described presents a mechanism by which personal beliefs of managers can influence decision-making on the capital structure as well as the business operations of companies in general.

As discussed further by Besley and Brigham (2015), company managers behave completely the opposite, due to cancellation of orders they have to modernize their own capacities in order to maintain the level of production, which requires high costs of investment in fixed assets. Namely, such companies must invest in new production capacities in order to avoid the possibility of initiating bankruptcy. The question is: how will they finance the necessary resources? In this case, companies with unfavorable prospects in terms of future business operations, will want to sell shares, because potential new losses 
could be shared with new investors, which actually shows a sort of (sui generis) hypocrisy of managers of such companies who, when issuing new shares, can meet legal requirements regarding the issue, but do not have to disclose unfavorable prospects in terms of the company's future business operations .A conclusion to the previous statement is that companies whose managers perceive favorable aspects, will not finance their business operations by issuing new shares, while companies whose managers have a pessimistic view of the future business operations want to be financed because of their own equity. In this way, the mechanism for the performance of personal managers' beliefs based on the experiences or emotions, regarding decisions on the capital structure and the future operations of companies, can be explained.

Of course, the main assumption in a traditional finance literature is that market participants, investors and managers make the rational decisions. However, in contrast to this behavioral finance which is based on human psychology, there is an alternative approach which calls into question definitions of the classical finance on economic rationality. In particular, psychological studies have found that people have unreasonably high confidence in their own decision making, which essentially means that most people have exaggerated confidence in their abilities (Bilgehan, 2014). It is particularly important that behavioral finance uses psychology and similar disciplines to explore why individual solutions, often deviate from the strictly rational choices. As Bilgehan (2014) further states, most people are aware that emotions affect financial decisions, thus analysis of behavioral finance expands the role of biased insights when making decisions. The greatest number of studies in behavioral finance refers to the behavior of investors, not only them, but also to the behavior of managers in financial decisionmaking in companies. The latest behavioral finance theories give an explanation how biases such as overconfidence and optimism can affect corporate decisions (Bilgehan, 2014). According to the definition of Hersh Shefrin, which Bilgehan (2014) cites, bias is nothing else than a predisposition towards errors if there is influence of some basic belief. By citing other authors Bilgehan (2014) also writes that biases and their presence in decision-making, provides an insight in connection with irrationality of individuals and thereby expands the general attitude of irrational behavior. There are also arguments in relation to financial decisions which are subject to psychological factors that affect decisions about capital structure, which deals with the area of the so-called behavioral finances. In line with this, behavioral finance thus uses the theory based on psychology that would explain certain market anomalies (Bilgehan, 2014).Managers must choose between debt and proprietary capital when making financial decisions says Bilgehan (2014), therefore psychological biases that affect financial decision-making by the managers are responsible for inconsistency in relation to what is expected or preferred by investors.

Hackbarth (2008) argues that optimism and overconfidence are described as reasoning in cases of uncertainty. He further argues that managers who perceive growth have tendency to achieve higher debt levels and more frequently recourse to issue new instruments of debt compared with managers who do not have such perceptions. As a result of this, the behavior of managers can cause considerable variations in the capital structure no matter the characteristics of the industry which companies belong to unchanged (Hackbarth, 2008). Hackbarth further says that managerial features, in relation to the growth and risk perceptions, are very important for decision-making on the capital structure, such as the issue of debt issuance. Namely, managers with higher expectations perceive the excessive increase in the earnings of their companies in the future and for this reason they use excessive external debt financing, thus when they approach the capital markets they already have debt preferences. In this model, a rational market reaction to a higher ratio between debt and equity will tend to erode the value of the firm. Stanišić et al. (2012) say that debt to equity ratio (see examples 1 and 2 in the Chapter 
on Methodology) is an indicator that is often used in models for predicting bankruptcy and assessing solvency of companies. Hackbarth (2008) also argues that decisions regarding capital structure represent tradeoff between not just corporate taxes and bankruptcy costs, but also a conflict of interest among claimholders. Therefore, there is a disadvantage in terms of any qualitative or quantitative guide which would explain the interaction between agency conflicts and managerial traits. In fact, there is general concern about the personal interests of managers who tend to create personal benefits (Jensen \& Meckling, 1976). Static models of capital structure, aforetime point out the prospect that debt, if the available funds are restrictive, forces managers to be less wasteful in terms of spending money. A dynamic model of capital structure requires a debt issuance discipline due to the inability to return to the initial level of leverage ratio. Given that the financial decisions in the companies are in the hands of their managers, one of the unresolved tasks in terms of capital structure decisions is which type of manager will choose discipline in regarding the level of debt, and the opposite which type of them will likely continue with the policy of increased borrowing in a dynamic environment. Due to the fact that bond holders anticipate investment behavior, the cost of debt is included in the value of the debt on the day of issuance as an agency cost of debt, in which case the underinvestment process creates a higher cost of risky debt (Hackbart, 2008).

In this paper an attempt will be made to explain the impact of some of the aforementioned factors on the shift of the financial break even and the level of net profit, using the net operating income approach. Primarily, we are interested in the influence of factors such as overconfidence and optimism on increasing the level of debt in the capital structure of companies, which will result in not only an increased level of systemic risk, measured by the coefficient of beta, but also in a lower level of net profit. Namely, if we imagine that there are two companies, which do not at all differ apart from the structure of capital, where in one there is a certain share of debt in total capital, while in the other there is solely fixed capital, a company that has no debt in the capital structure will achieve a higher level of net profit, for the simple reason that in the financial section of the income statement there will be no payments of interest due. This work will show that the financial leverage can lead (not necessarily) to the fall in the level of net profit, which will be shown in the case of Puma Company in the net profit account examples.

\section{METHODOLOGY}

The influence of psychological factors on the capital structure change and consequently on net profit can be illustrated with the net operating income approach:

We will set the following equality of Van Horne's (1993),

$\mathrm{k}_{\mathrm{d}}=\mathrm{F} / \mathrm{B}$

where, $\mathrm{F}$ is the annual interest expense, $\mathrm{B}$ is the market value of existing debt, $\mathrm{k}_{\mathrm{d}}$ is required return to debt (cost of debt).

$\mathrm{k}_{\mathrm{e}}=\mathrm{E} / \mathrm{S}$

where, $\mathrm{E}$ is earnings attributable to shareholders, $\mathrm{S}$ is the market value of equity, $\mathrm{k}_{\mathrm{e}}$ is required return on levered equity (cost of levered equity). 


$$
\mathrm{k}_{\mathrm{u}}=\mathrm{EBIT} / \mathrm{V}
$$

where, EBIT (earning before interest and taxes) $=\mathrm{NOI}$ is net operating income, $\mathrm{V}$ is the total market value of the company (value of shares in the unlevered company), $\mathrm{k}_{\mathrm{u}}$ is required return to unlevered equity (cost of unlevered equity), and also this equation applies:

$$
\mathrm{V}=\mathrm{B}+\mathrm{S}
$$

\section{Derivation}

From the previous equations, follows:

$$
\begin{aligned}
& \mathrm{EBIT}=\mathrm{F}+\mathrm{E} \\
& \mathrm{k}_{\mathrm{u}}=(\mathrm{F}+\mathrm{E}) /(\mathrm{B}+\mathrm{S}) \\
& \mathrm{k}_{\mathrm{u}}=\mathrm{F} /(\mathrm{B}+\mathrm{S})+\mathrm{E} /(\mathrm{B}+\mathrm{S}) \\
& \mathrm{k}_{\mathrm{u}}=\mathrm{k}_{\mathrm{d}} \cdot \mathrm{B} /(\mathrm{B}+\mathrm{S})+\mathrm{k}_{\mathrm{e}} \cdot \mathrm{S} /(\mathrm{B}+\mathrm{S})
\end{aligned}
$$

Using net operating income approach with the copied examples (Van Horne, 1993), for the reasons of simplifications, we obtain the following results.

If a company with $\$ 1000$ debt and with an interest rate of $10 \%$, and the expected value of NOI is $\$ 1000$, the total capitalization $\mathrm{k}_{\mathrm{u}}$ is $15 \%$. We will express the value of the company in the following manner:

\begin{tabular}{cc}
\hline NOI & 1000 \\
$\mathrm{k}_{\mathrm{u}}$ & 0,15 \\
$\mathrm{~V}=\mathrm{B}+\mathrm{S}$ & 6667 \\
$\mathrm{~B}$ & 1000 \\
$\mathrm{~S}$ & 5667 \\
\hline
\end{tabular}

Example 1.Influence of debt on capital structure Source: Van Horne (1997, p. 278)

$$
\begin{aligned}
& \text { Interest }(\mathrm{I})=\mathrm{B} \bullet \mathrm{kd}=1000 \$ \bullet 0,1=100 \$ \\
& \mathrm{E}=\mathrm{NOI}-\mathrm{I}=1000 \$-100 \$=900 \$ \\
& \mathrm{k}_{\mathrm{e}}=\mathrm{E} / \mathrm{S}=900 \$ / 5667 \$=0,1588=15,88 \%
\end{aligned}
$$

Using now the equations of Fernandez (2003), we can calculate beta-coefficients as:

$$
\begin{aligned}
& \beta_{\mathrm{l}}=\left(\mathrm{k}_{\mathrm{e}}-\mathrm{R}_{\mathrm{f}}\right) / \mathrm{P}_{\mathrm{m}} \\
& \beta_{\mathrm{u}}=\left(\mathrm{k}_{\mathrm{u}}-\mathrm{R}_{\mathrm{f}}\right) / \mathrm{P}_{\mathrm{m}} \\
& \beta_{\mathrm{d}}=\left(\mathrm{k}_{\mathrm{d}}-\mathrm{R}_{\mathrm{f}}\right) / \mathrm{P}_{\mathrm{m}}
\end{aligned}
$$

with the necessary prerequisites that $\mathrm{R}_{\mathrm{f}}=2 \%, \mathrm{P}_{\mathrm{m}}=\mathrm{E}\left(\mathrm{R}_{\mathrm{m}}-\mathrm{R}_{\mathrm{f}}\right)=5 \%$ provided that the expected return of the market portfolio is $\mathrm{E}\left(\mathrm{R}_{\mathrm{m}}\right)=7 \%$, where $\mathrm{R}_{\mathrm{f}}$ is risk free rate, $\mathrm{P}_{\mathrm{m}}$ is market risk premium, followed by beta coefficients, see (Sharpe, Alexander \& Bailey, 1995): 


$$
\begin{aligned}
& \beta_{1}=(15,88-2) / 5=2,776 \\
& \beta_{u}=(15-2) / 5=2,6 \\
& \beta_{d}=(10-2) / 5=1,6
\end{aligned}
$$

Net operating income approach means that the capitalization rate $\mathrm{k}_{\mathrm{u}}$ and the level of cost of debt $\mathrm{k}_{\mathrm{d}}$ remains the same regardless of the degree of use of financial leverage. In this case the required rate on levered equity $\mathrm{k}_{\mathrm{e}}$ grows linearly depending on the degree of utilization of financial leverage.

Increasing the amount of debt on $\$ 3000$ with the use of income from issuing debt by which the shares are bought and the same interest rate on debt $k_{d}=10 \%$, the value of the company will be as follows:

\begin{tabular}{cc}
\hline EBIT $=$ NOI & 1000 \\
$\mathrm{k}_{\mathrm{u}}$ & 0,15 \\
$\mathrm{~V}$ & 6667 \\
$\mathrm{~B}$ & 3000 \\
$\mathrm{~S}$ & 3667 \\
\hline
\end{tabular}

Example 2. Influence of increased debt on capital structure Source: Van Horne (1997, p. 278)

$$
\begin{aligned}
& \text { Interest }(\mathrm{I})=\mathrm{B} \cdot \mathrm{k}_{\mathrm{d}}=3000 \$ \bullet 0,1=300 \$ \\
& \mathrm{E}=\mathrm{NOI}-\text { interest }=1000 \$-300 \$=700 \$ \\
& \mathrm{k}_{\mathrm{e}}=\mathrm{E} / \mathrm{S}=700 \$ / 3667 \$=0,1909=19.09 \%
\end{aligned}
$$

Then the corresponding beta, with unchanged preconditions for the values of Rf and Pm, will be:

$\beta_{1}=(19,09-2) / 5=3,42$

$\beta_{\mathrm{u}}=(15-2) / 5=2,6$

$\beta_{\mathrm{d}}=(10-2) / 5=1,6$

Thus, with increasing the levels of debt, in regard to higher debt / equity ratio, the systemic risk of the company, measured with coefficient beta, grows steadily, which in fact is the evidence that this hypothesis $\mathrm{H} 1$ is true, that the level of debt affects the growth of systemic risks measured by the beta.

If the ratio of debt and permanent capital is fixed, the relevant equation will be as follows, based on equation (1), which reads:

$\mathrm{k}_{\mathrm{u}}=\mathrm{k}_{\mathrm{d}} \cdot \mathrm{B} /(\mathrm{B}+\mathrm{S})+\mathrm{k}_{\mathrm{e}} \cdot \mathrm{S} /(\mathrm{B}+\mathrm{S})$

which implies the following,

$$
\mathrm{k}_{\mathrm{e}}=\mathrm{k}_{\mathrm{u}}+(\mathrm{B} / \mathrm{S})\left(\mathrm{k}_{\mathrm{u}}-\mathrm{k}_{\mathrm{d}}\right)
$$

If EBIT $>0$ and if as Besley \& Brigham (2015) write,

\section{$\mathrm{EBIT}=\mathrm{I}$}

where I represents long term interest costs, then we get a financial break even, which may present itself in an equation: 


$$
\mathrm{EBIT}-\mathrm{I}=0
$$

Namely, at this point the operating profit EBIT is sufficient to cover all fixed financial costs that appear as consequences of the companies' debts. In this case, EBT (earnings before taxes) is equal to zero, which implies that net profit is equal to zero. Financing break even thus is the point at which the company will neutralize all costs as argued by Besley \& Brigham (2015) and operational ones which are calculated in the operational section of the income statement and financial ones which are calculated in the financial section of the income statement.

\section{Independence of EBIT from capital structure}

The crucial question is whether capital structure means anything at all? Namely, whether the companies can influence the cost of capital and request return by changing the combinations of funding. In order to answer this question, we will perform an analysis of what happens to the value of the company and the costs of capital if the relation of debt and constant equity is changed, that is if the level of use of finance leverage is changing. In order to depict the analysis as simple as possible, certain previous assumptions should be made, as following:

Debt to equity ratio in the total capital changes by bond issuance, which is used to redeem shares accordingly by emitting equity that would settle the debt. This means that changes in capital structure occur instantly. We will also assume that there are no transaction costs. We also assume that the entire net profit, available to shareholders, is paid in the form of dividends and that the future operating income is not expected to grow.

The following three rates will be used:

$\mathrm{k}_{\mathrm{d}}=\mathrm{F} / \mathrm{B}=$ (annual interest expense/market value of existing debt)

$\mathrm{k}_{\mathrm{e}}=\mathrm{E} / \mathrm{S}=$ (earnings attributable to shareholders/market value of issued shares )

$\mathrm{k}_{\mathrm{u}}=\mathrm{O} / \mathrm{V}=$ (net operating income/total market value of the company)

given that EBIT=NOI (Net operating income) and we apply the equations:

EBIT(NOI) $-\mathrm{F}=\mathrm{EBT}$

$\mathrm{EBT}(1-\mathrm{T})=\mathrm{E}$

if the tax rate $\mathrm{T}=0$, then

$\mathrm{EBT}=\mathrm{E}$

accordingly, it follows that

$\mathrm{EBIT}=\mathrm{F}+\mathrm{E}$

where

$\mathrm{EBIT}(\mathrm{NOI})=\mathrm{O}=$ net operating income, then:

$\mathrm{k}_{\mathrm{u}}=(\mathrm{F}+\mathrm{E}) /(\mathrm{B}+\mathrm{S})$

or by equation (1)

$\mathrm{k}_{\mathrm{u}}=\mathrm{k}_{\mathrm{d}} \cdot \mathrm{B} /(\mathrm{B}+\mathrm{S})+\mathrm{k}_{\mathrm{e}} \cdot \mathrm{S} /(\mathrm{B}+\mathrm{S})$

or by alternating by equation (2) it follows that:

$\mathrm{k}_{\mathrm{e}}=\mathrm{k}_{\mathrm{u}}+(\mathrm{B} / \mathrm{S})\left(\mathrm{k}_{\mathrm{u}}-\mathrm{k}_{\mathrm{d}}\right)$ 
Let's examine now what will happen with rates, $\mathrm{k}_{\mathrm{d}}, \mathrm{k}_{\mathrm{e}}$ and $\mathrm{k}_{\mathrm{u}}$, if the level of use of financial leverage is increased which is measured by the increasing ratio of $\mathrm{B} / \mathrm{S}$. Using the net operating income approach, with the assumed examples 1 and 2, which have been previous explained, we realize that the required return on levered equity $\mathrm{k}_{\mathrm{e}}$ increases with the degree of utilization of financial leverage (Van Horne, 1997). Implication of this approach is that the capital structure does not affect the total value of the company. A key prerequisite for such a model, according to Van Horne (1997) is that the overall capitalization rate $\mathrm{k}_{\mathrm{u}}$ is constant, regardless of the degree of use of financial leverage. The market therefore performs capitalization of value of the company as a whole and, as a consequence the partition of capital structure on a long debt and equity is irrelevant. The increasing use of debt in this case is equal to the growth of required return on levered equity $\mathrm{k}_{\mathrm{e}}$. Thus, with the increase in the level of use of financial leverage every company becomes riskier (Van Horne, 1997). Investors in this case punish the shares of these companies in a way that they require more returns, by directly following the growth of the ratio of debt and equity. As long as the level of $\mathrm{k}_{\mathrm{d}}$ is constant, $\mathrm{k}_{\mathrm{e}}$ is a linear function of debt to equity ratio which is clearly evident from equation (2). Given that financial leverage cannot change total cost of capital of the company $\mathrm{k}_{\mathrm{u}}$, net operating income approach assumes that there is no optimal capital structure (Van Horne, 1997). Namely, we obtained the result that the net operating income (EBIT) is fully independent of the structure of capital, apropos capital structure does not affect EBIT=NOI.

We will now consider the behavioral model Modigliani - Miller in support of the independence of the total value of the company and the cost of capital from the capital structure (Van Horne, 1997). Modigliani and Miller offer a behavioral justification for the constant cost of capital $\mathrm{k}_{\mathrm{u}}$ and through all the extents of use of financial leverage while claiming that net operating income approach explains the relationship between the cost of capital and the use of financial leverage (Van Horne, 1997). Their attitude is based on the fact that no matter how we divide the capital structure between debt and equity, the result is a constant value, and the preservation of value for investors exists. Thus, the total investment value of a company depends on its profitability and risk and remains unchanged in terms of the relative change in the financial capitalization (Van Horne, 1997), or the changes in the ratio of debt and equity. The attitude of (MM) is actually based on the fact that investors are able to substitute the use of "personal" financial leverage with "company" financial leverage, thereby forming a response to any capital structure that the company can form (Van Horne, 1997). A previous attitude rests on the fact that the company is unable to do anything for its shareholders what they themselves have not been able to do, in terms of creating financial leverage, so the changes in capital structure do not have valuable sense under conditions of perfect capital market, which (MM) implies (Van Horne, 1997). Thus, the two companies that are "identical in all respects" except in the structure of capital, must be equal in the total value. If this is not fulfilled, there is the possibility of arbitration which will lead to these two companies being sold on the market with equal total values (Van Horne, 1997).

Thus, from what has previously been written, it is possible to conclude that company managers can shape the capital structure on the basis of their own preferences, and that it will not affect the operating income of the company, however it will definitely affect the net profit which depends on the level of interest that the company must periodically pay to its creditors, indirectly confirming hypothesis $\mathrm{H}$.

The further methodological approach is applied to two case studies on companies such as Puma and Adidas as two of the world's leading manufacturers of sports equipment, where on the basis of available data from the statements of financial position and the income statements, the net profits of these companies are analyzed, respectively. Then a comparative analysis will be made of the results obtained for the net profits of the two companies that will provide an insight in their financial performance that will be presented in the account examples topic of this paper. 


\section{Net profit account examples over companies such as Puma and Adidas}

Given that Puma company's EBIT in 2015 was equal to $€ 96.3$ million and that Adidas company's EBIT in 2015 was equal to $€ 1059$ million, and that the financial results based on the interest collected and paid were equal to $€ 11.2$ million and $€ 21$ million respectively, the results obtained for EBT, from the income statements of these two companies were $€ 85$ million and $€ 1039$ million. So, for Puma Company in 2015 it was enough to keep its EBIT at $€ 11.2$ million to reach the financial break even and neutralize not only the operational, but financial costs as well. Similarly, in 2015 Adidas Company would reach the financial break even in the case where its EBIT is $€ 21$ million. Summarized comparative financial data of the companies in 2015 are presented in table at the end of this paper. Given that both companies achieved substantially higher values of EBIT, they could quite simply serve their due obligations because of financial arrangements. Given that both companies are levered and pay interest on the basis of financial agreements, from the previously analyzed facts, the influence on systemic risk measured with coefficient beta is clear.

Given the fact that the company's EBIT in 2014 was equal to $€ 128.0$ million (Puma) and that the company's EBIT in 2014 was equal to $€ 883$ million (Adidas) and that the financial results based on the interest collected and paid were equal to $€ 6.2$ million and $€ 48$ million respectively, the results obtained for EBT from income statements of these two companies were $€ 121.8$ million and $€ 835$ million. Summarized comparative financial data of the companies in 2014 are presented in table 2 at the end of the paper. So, it is clear that Puma Company had better financial results in 2014 than in 2015. In contrast, Adidas improved its financial position in 2015 in comparison to 2014.

Net profit of Puma Company in 2015 (from income statement) was €61.7 million while net profit of Adidas Company was $€ 640$ million. Comparative analysis of the net profits of these two companies may be shown as a percentage of net profit in relation to total sales, which was $1.82 \%$ of Puma Company, and 3.78\% of Adidas Company, which shows that Adidas made two times more net profit compared to total sales of Puma Company. The ratio of EBIT in accordance with the total sales of Puma Company was $2.84 \%$, while this amount was $6.26 \%$ of Adidas Company, which practically means that Adidas Company realizes significantly lower operating costs of Puma Company. The ratio of EBIT and financial expenses (interest) of Puma Company was 8.6, while of Adidas company was 50.43, (see table 1.) and therefore the interest coverage with operating income of Adidas Company is much higher than the indicator of interest coverage of Puma.

Net profit of Puma Company in 2014 (from income statement) was $€ 84.8$ million while the net profit of Adidas Company was $€ 496$ million. Comparative analysis of the net profits of these two companies may be shown as a percentage of net profit in relation to total sales which was $2.85 \%$ of Puma Company and $3.41 \%$ of Adidas, which shows that Adidas implemented slightly more net profit compared to total sales of Puma Company. The ratio of EBIT in accordance with the total sales of Puma company was $4.31 \%$, while this amount of Adidas company was $6.08 \%$, which practically means that Adidas did not realize significantly lower operating costs in comparison to Puma in 2014. The ratio of EBIT and financial expenses (interest) of Puma Company was 20.65, while of Adidas Company it was 18.4, (see table 2.) and therefore the interest coverage with operating income of Puma is higher than the indicator of interest coverage of Adidas in 2014.

It is obvious from the income statement that Puma has a significantly lower indicator of TIE (times interest earned) in 2015 when it was 8.6, compared to 2014 when it was 20.65 , which is due not only to increased financial expenses, but also to a lower level of EBIT (earnings before interest and taxes), 
therefore, the net profit level was lower in 2015 when it amounted to $€ 61.7$ million compared to 2014 when it amounted to $€ 84.8$ million. The opposite happened in the Adidas Company, where the TIE indicator in 2015 was 50.4 and it was significantly higher compared to 2014 when it was 18.4 , which is due not only to the higher level of EBIT, but also to the more favorable level of financial result achieved by a higher level of financial income in 2015 (see appendix).

\section{CONCLUSION}

This paper discusses the impact of behavioral finance on the decisions of managers and investors. It specifically explains the influence of certain psychological factors on the manager's capital structure decision-making process. These psychological factors can affect the financial part of income statement, as confirmed in this paper. Namely, the biases and personal beliefs of the managers and investors which are defined in literature as overconfidence and optimism lead to the fact that, managers of the companies in particular, form the capital structure of the companies on the basis of their own affinities, thereby directly affecting not only the level of risk of shares of their companies, but also the profit of those companies, along with the influence on the moving of financial breakeven which is discussed in the financial section of the income statement. Thus, some aspects of psychology of managers significantly affect not only the capital structure, but also the company's profitability and level of risk, thus confirming result that decisions about the capital structure change can affect the changing of the net profit.

Therefore, financial leverage definitely makes sense when a company invests borrowed funds at a higher rate of return than the interest rate on debt, in which case managers have correctly estimated the level of net sales and cost of sales that generate a higher level of EBIT and net profit (as shown in the case of Adidas where the TIE indicator is growing) when the company actually has "healthy" business operations. In this case, the company generates a higher ROE (return on equity), which, along with the tax advantage of financial leverage, where the interest on the debt is not taxed, brings increased benefits to the company and shareholders. However, financial leverage can also cause serious problems in the event of a company facing poor business conditions such as a lower volume of net sales and a higher level of costs than expected, when the EBIT level can drop significantly. Since the cost of debt is usually contractually fixed and repayable, such interest payments can impose a large financial burden on the company that leads to a loss of net profit (as shown in Puma's case where the TIE indicator decreases). Then, the financial leverage works to the detriment of the company and its shareholders. In general, it can be concluded that companies with higher levels of debt have higher expected returns in the case when the business operations are habitually good, but are also exposed to a higher risk of loss when the business operations are worse than expected. Contrary to this, companies with a low level of debt are less risky, but they in some ways disclaim the possibility of financial leverage in order to increase their ROE (return on equity).

\section{REFERENCES}

Ackert, L. F. (2014). Traditional and Behavioral Finance: Chapter 2. In H. Kent Baker \& Victor Ricciardi (Ed.) Investor Behavior: The Psychology of Financial Planning and Investing (pp. 25-41). Hoboken, NJ: John Wiley \& Sons. DOI: $10.1002 / 9781118813454 . c h 2$

Altman, M. (2014). Behavioral Economics, Thinking Processes, Decision Making, and Investment Behavior: Chapter 3. In H. Kent Baker \& V. Ricciardi (Ed.). Investor Behavior Investor Behavior: The Psychology of Financial Planning and Investing. DOI: 10.1002/9781118813454.ch3 
Baker, H. K., \& Ricciardi, V. (2014). Investor Behavior: An Overview: Chapter 1. In H. K. Baker \& V. Ricciardi (Ed.) Investor Behavior: The Psychology of Financial Planning and Investing (pp. 3-24). Hoboken, NJ: John Wiley \& Sons. DOI: 10.1002/9781118813454.ch1

Besley, S., \& Brigham, E. F. (2015). Poslovne finansije: CFIN. Beograd: Data status. In Serbian.

Bilgehan, T. (2014). Psychological biases and the capital structure decisions: a literature review. Theoretical and Applied Economics, XXI (12), 123-142.

Bogan, V. L. (2014). Household Investment Decisions: Chapter 5. In H. K. Baker \& V. Ricciardi (Ed.) Investor Behavior: The Psychology of Financial Planning and Investing (pp. 83-98). Hoboken, NJ: John Wiley \& Sons. DOI: $10.1002 / 9781118813454 . c h 5$

Fairchild, R. (2014). Emotions in the Financial Markets: Chapter 19. In H. K. Baker \& V. Ricciardi (Ed.) Investor Behavior: The Psychology of Financial Planning and Investing (pp. 347-364). Hoboken, NJ: John Wiley \& Sons. DOI: 10.1002/9781118813454.ch19

Fama, E. (1970). Efficient capital markets: a review of theory and empirical work. Journal of Finance, 25(2), 383417. DOI: $10.2307 / 2325486$

Farrel, J. (2014). Demographic and Socioeconomic factors of Investors: Chapter 7. In H. K. Baker \& V. Ricciardi (Ed.) Investor Behavior: The Psychology of Financial Planning and Investing (pp. 117-134). Hoboken, NJ: John Wiley \& Sons. DOI: 10.1002/9781118813454.ch7

Fernández, P. (2003). Levered and Unlevered Beta. Retrieved November 1, 2016, from http://www.iese.edu/ research/pdfs/DI-0488-E.pdf

Fisher, G. S. (2014). Advising the Behavioral Investor-Lessons from the Real World: Chapter 15. In H. K. Baker \& V. Ricciardi (Ed.) Investor Behavior: The Psychology of Financial Planning and Investing (pp. 265-283). Hoboken, NJ: John Wiley \& Sons. DOI: 10.1002/9781118813454.ch15

Hackbarth, D. (2008). Managerial Traits and Capital Structure Decisions. Journal of Financial and Quantitative Analysis, 43(4), 843-881. DOI: 10.2139/ssrn.362740

Jensen, M., \& Meckling, W. (1976). The Theory of the Firm: Managerial Behavior, Agency Costs and Ownership Structure. Journal of Financial Economics, 3 (1976), 305-360.

Kahneman, D., \& Tversky, A. (1979). Prospect Theory: An Analysis of Decision under Risk. Econometrica, 47(2), 263-291. DOI: $10.2307 / 1914185$

Kramer, L. A. (2014). Human Psychology and Market Seasonality: Chapter 20. In H. K. Baker \& V. Ricciardi (Ed.) Investor Behavior: The Psychology of Financial Planning and Investing (pp. 365-383). Hoboken, NJ: John Wiley \& Sons. DOI: $10.1002 / 9781118813454 . \operatorname{ch} 20$

Mankiw, G. N. (2008). Principi ekonomije. Beograd: Ekonomski fakultet. In Serbian.

Mansour, W., \& Ilassi, M. (2014). The Effect of religion on Financial and Investing Decision: Chapter 8. In H. K. Baker \& V. Ricciardi (Ed.) Investor Behavior: The Psychology of Financial Planning and Investing. Hoboken, NJ: John Wiley \& Sons. DOI: 10.1002/9781118813454.ch8

Markowitz, H. (1959). Portfolio Selection: Efficient Diversification of Investments. Yale University Press. Retrieved from http://www.jstor.org/stable/j.ctt1bh4c8h

Ricciardi, V., \& Rice, D. (2014). Risk Perception and risk Tolerance: Chapter 18. In H. K. Baker \& V. Ricciardi (Ed.) Investor Behavior: The Psychology of Financial Planning and Investing (pp. 327-345). Hoboken, NJ: John Wiley \& Sons. DOI: 10.1002/9781118813454.ch18

Ritter,J. R. (1988). The Buying and Selling behaviour of Individual Investors at the Turn of the Year. The Journal of Finance 43(3), 701-717. DOI: 10.2307/2328193

Sharpe, W. F., Alexander, G. J., \& Bailey, J. V. (1995). Investments. Englewood Cliffs, New Jersey: Prentice Hall.

Stanišić, N., Radojević, T., Mizdraković, V., Stanić, N. (2012). Capital efficiency analysis of Serbian companies. Singidunum Journal of Applied Sciences, 9(2), 41-49.

Van Horne, J. C. (1997). Financial management and policy. Upper Saddle River, NJ: Prentice Hall.

Žigić, D., Hadžić, M. (2012). The process of risk management in financial business. Singidunum Journal of Applied Sciences, 9(2), 33-40. 
Xiao,J. J. (2014). Money and Happiness - Implications for Investor Behavior: Chapter 9. In H. K. Baker \& V. Ricciardi (Ed.) Investor Behavior: The Psychology of Financial Planning and Investing (pp. 153-169). Hoboken, NJ: John Wiley \& Sons. DOI: 10.1002/9781118813454.ch9

\section{APPENDIX}

T.1 Consolidated Statement of Financial Position

\begin{tabular}{|c|c|c|c|}
\hline & Notes & $\frac{31.12 .2015}{€ \text { million }}$ & $\begin{array}{r}31.12 .2014 \\
\quad \text { million }\end{array}$ \\
\hline \multicolumn{4}{|l|}{ ASSETS } \\
\hline Cash and cash equivalents & 3 & 338.8 & 401.5 \\
\hline Inventories & 4 & 657.0 & 571.5 \\
\hline Trade receivables & 5 & 483.1 & 449.2 \\
\hline Income tax receivables & 22 & 50.5 & 75.0 \\
\hline Other current financial assets & 6 & 76.8 & 93.6 \\
\hline Other current assets & 7 & 78.6 & 91.8 \\
\hline Current assets & & $1,684.8$ & $1,682.5$ \\
\hline Deferred taxes & 8 & 219.8 & 178.8 \\
\hline Property, plant and equipment & 9 & 232.6 & 224.0 \\
\hline Intangible assets & 10 & 403.3 & 391.4 \\
\hline Investments in associates & 11 & 15.2 & 15.2 \\
\hline Other non-current financial assets & 12 & 39.3 & 34.6 \\
\hline Other non-current assets & 12 & 25.2 & 23.4 \\
\hline Non-current assets & & 935.5 & 867.5 \\
\hline Total assets & & $2,620.3$ & $2,549.9$ \\
\hline
\end{tabular}

\begin{tabular}{|c|c|c|c|}
\hline & Notes & $\frac{31.12 .2015}{E \text { million }}$ & $\begin{array}{r}31.12 .2014 \\
\quad \text { m million }\end{array}$ \\
\hline \multicolumn{4}{|l|}{ LIABILITIES AND SHAREHOLDERS' EQUITY } \\
\hline Current financial liabilities & 13 & 14.0 & 19.8 \\
\hline Trade payables & 13 & 519.7 & 515.2 \\
\hline Income taxes & 22 & 49.7 & 58.8 \\
\hline Other current provisions & 16 & 52.7 & 69.5 \\
\hline Liabilities from acquisitions & 17 & 3.0 & 0.5 \\
\hline Other current financial liabilities & 13 & 115.9 & 51.0 \\
\hline Other current liabilities & 13 & 125.1 & 107.8 \\
\hline Current liabilities & & 880.0 & 822.6 \\
\hline Deferred taxes & 8 & 64.2 & 54.6 \\
\hline Pension provisions & 15 & 23.8 & 26.0 \\
\hline Other non-current provisions & 16 & 23.5 & 23.1 \\
\hline Liabilities from acquisitions & 17 & 0.0 & 2.5 \\
\hline Other non-current financial liabilities & 13 & 7.2 & 0.3 \\
\hline Other non-current liabilities & 13 & 2.2 & 2.5 \\
\hline Non-current liabilities & & 121.0 & 109.0 \\
\hline Subscribed capital & 18 & 38.6 & 38.6 \\
\hline Group reserves & 18 & 162.5 & 176.0 \\
\hline Retained earnings & 18 & $1,441.7$ & $1,412.0$ \\
\hline Treasury stock & 18 & -31.4 & -31.4 \\
\hline Equity attributable to the shareholders of the parent & & $1,611.3$ & $1,595.2$ \\
\hline Non-controlling interest & 18 & 8.0 & 23.1 \\
\hline Shareholders' equity & 18 & $1,619.3$ & $1,618.3$ \\
\hline Total liabilities and shareholders' equity & & $2,620.3$ & $2,549.9$ \\
\hline
\end{tabular}

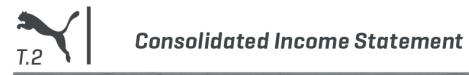

\begin{tabular}{|c|c|c|c|}
\hline & Notes & $€$ million & $\begin{array}{r}2014 \\
€ \text { million }\end{array}$ \\
\hline Sales & 25 & $3,387.4$ & $2,972.0$ \\
\hline Cost of sales & 25 & $-1,847.2$ & $-1,586.7$ \\
\hline Gross profit & 25 & $1,540.2$ & $1,385.4$ \\
\hline Royalty and commission income & & 16.5 & 19.4 \\
\hline Other operating income and expenses & 20 & $-1,460.5$ & $-1,276.8$ \\
\hline Operating income (EBIT) & & 96.3 & 128.0 \\
\hline Result from associated companies & 21 & 1.0 & 1.3 \\
\hline Financial income & 21 & 11.2 & 4.8 \\
\hline Financial expenses & 21 & -23.4 & -12.3 \\
\hline Financial result & & -11.2 & -6.2 \\
\hline Earnings before taxes (EBT) & & 85.0 & 121.8 \\
\hline Taxes on income & 22 & -23.3 & -37.0 \\
\hline Consolidated net earnings for the year & & 61.7 & 84.8 \\
\hline attributable to: Non-controlling interest & 18 & -24.6 & -20.8 \\
\hline Equity holders of the parent (net earnings) & & 37.1 & 64.1 \\
\hline Earnings per share $(€)$ & 23 & 2.48 & 4.29 \\
\hline Earnings per share $(€)$ - diluted & 23 & 2.48 & 4.29 \\
\hline Weighted average shares outstanding (million) & 23 & 14.940 & 14.940 \\
\hline Weighted average shares outstanding. diluted (million) & 23 & 14.940 & 14.940 \\
\hline
\end{tabular}

Source:http://about.puma.com/damfiles/default/investor-relations/financial-reports/en/2015/GB_2015_ENG_Final_links_low-res-8932dbc11383cd85124e1ba63d86b5cc.pdf 


\section{CONSOLIDATED STATEMENT OF FINANCIAL POSITION}

\section{ADIDAS AG CONSOLIDATED STATEMENT OF FINANCIAL POSITION (IFRS) € IN MILLIONS}
Note
Dec. 31, 2015
Dec. 31, 2014
Change in \%

\section{Assets}

\begin{tabular}{|c|c|c|c|c|}
\hline Cash and cash equivalents & 5 & 1,365 & 1,683 & [18.9] \\
\hline Short-term financial assets & 6 & 5 & 5 & 0.8 \\
\hline Accounts receivable & 7 & 2,049 & 1,946 & 5.3 \\
\hline Other current financial assets & 8 & 367 & 398 & (7.8) \\
\hline Inventories & 9 & 3,113 & 2,526 & 23.2 \\
\hline Income tax receivables & 34 & 97 & 92 & 4.9 \\
\hline Other current assets & 10 & 489 & 425 & 15.2 \\
\hline Assets classified as held for sale & 11 & 12 & 272 & (95.7) \\
\hline Total current assets & & 7,497 & 7,347 & 2.0 \\
\hline Property, plant and equipment & 12 & 1,638 & 1,454 & 12.7 \\
\hline Goodwill & 13 & 1,392 & 1,169 & 19.1 \\
\hline Trademarks & 14 & 1,628 & 1,432 & 13.7 \\
\hline Other intangible assets & 14 & 188 & 162 & 16.0 \\
\hline Long-term financial assets & 15 & 140 & 129 & 9.0 \\
\hline Other non-current financial assets & 16 & 99 & 42 & 135.9 \\
\hline Deferred tax assets & 34 & 637 & 577 & 10.4 \\
\hline Other non-current assets & 17 & 124 & 105 & 17.7 \\
\hline Total non-current assets & & 5,846 & 5,070 & 15.3 \\
\hline Total assets & & 13,343 & 12,417 & 7.5 \\
\hline
\end{tabular}

Rounding differences may arise in percentages and totals.

The accompaning notes are an inercal patrof thes consolidated financial statements.

ADIDAS AG CONSOLIDATED STATEMENT OF FINANCIAL POSITION (IFRS) € INMILLIONS

$\begin{array}{llll}\text { Note } & \text { Dec. 31, } 2015 \text { Change in \% }\end{array}$

Liabilities and equity

\begin{tabular}{ll}
\hline Short-term borrowings & 18 \\
\hline Accounts payable & 19 \\
\hline Other current financial liabilities & 34 \\
\hline Income taxes & 20 \\
\hline Other current provisions & 21 \\
\hline Current accrued liabilities & 22 \\
\hline Other current liabilities & 11 \\
\hline Liabilities classified as held for sale &
\end{tabular}

Dec. 31, 2014

Change in \%

\begin{tabular}{|c|c|c|c|c|}
\hline Total current liabilities & & 5,364 & 4,378 & 22.5 \\
\hline Long-term borrowings & 18 & 1,463 & 1,584 & (7.6) \\
\hline Other non-current financial liabilities & 23 & 18 & 9 & 101.8 \\
\hline Pensions and similar obligations & 24 & 273 & 284 & (4.2) \\
\hline Deferred tax liabilities & 34 & 368 & 390 & (5.8) \\
\hline Other non-current provisions & 20 & 50 & 38 & 30.4 \\
\hline Non-current accrued liabilities & 21 & 120 & 81 & 48.3 \\
\hline Other non-current liabilities & 25 & 40 & 35 & 16.8 \\
\hline Total non-current liabilities & & 2,332 & 2,422 & (3.7) \\
\hline Share capital & & 200 & 204 & (2.0) \\
\hline Reserves & & 592 & 581 & 1.9 \\
\hline Retained earnings & & 4,874 & 4,839 & 0.7 \\
\hline Shareholders' equity & 26 & 5,666 & 5,624 & 0.7 \\
\hline Non-controlling interests & 27 & (18) & (7) & (166.2) \\
\hline Total equity & & 5,648 & 5,618 & 0.5 \\
\hline Total liabilities and equity & & 13,343 & 12,417 & 7.5 \\
\hline
\end{tabular}

Rounding differences may arise in percentages and totals.

The accompanying notes are an integral part of these consolidated financial statements. 


\section{CONSOLIDATED INCOME STATEMENT}

ADIDAS AG CONSOLIDATED INCOME STATEMENT (IFRS) € INMILLIONS

\begin{tabular}{|c|c|c|c|c|}
\hline & Note & $\begin{array}{r}\text { Year ending } \\
\text { Dec. 31, } 2015\end{array}$ & $\begin{array}{r}\text { Year ending } \\
\text { Dec. 31, } 2014\end{array}$ & Change \\
\hline Net sales & 36 & 16,915 & 14,534 & $16.4 \%$ \\
\hline Cost of sales & & 8,748 & 7,610 & $14.9 \%$ \\
\hline Gross profit & & 8,168 & 6,924 & $18.0 \%$ \\
\hline [\% of net sales] & & $48.3 \%$ & $47.6 \%$ & $0.6 \mathrm{pp}$ \\
\hline Royalty and commission income & & 119 & 102 & $16.1 \%$ \\
\hline Other operating income & 30 & 96 & 138 & $(30.3 \%)$ \\
\hline Other operating expenses & $12,14,31$ & 7,289 & 6,203 & $17.5 \%$ \\
\hline [\% of net sales] & & $43.1 \%$ & $42.7 \%$ & $0.4 \mathrm{pp}$ \\
\hline Goodwill impairment losses & 13 & 34 & 78 & $(55.9 \%)$ \\
\hline Operating profit & & 1,059 & 883 & $19.9 \%$ \\
\hline [\% of net sales] & & $6.3 \%$ & $6.1 \%$ & $0.2 \mathrm{pp}$ \\
\hline Financial income & 33 & 46 & 19 & $140.5 \%$ \\
\hline Financial expenses & 33 & 67 & 67 & (1.2\%) \\
\hline Income before taxes & & 1,039 & 835 & $24.4 \%$ \\
\hline [\% of net sales] & & $6.1 \%$ & $5.7 \%$ & $0.4 \mathrm{pp}$ \\
\hline Income taxes & 34 & 353 & 271 & $30.1 \%$ \\
\hline [\% of income before taxes] & & $34.0 \%$ & $32.5 \%$ & $1.5 \mathrm{pp}$ \\
\hline Net income from continuing operations & & 686 & 564 & $21.6 \%$ \\
\hline [\% of net sales] & & $4.1 \%$ & $3.9 \%$ & $0.2 \mathrm{pp}$ \\
\hline Losses from discontinued operations, net of tax & 3 & (46) & (68) & $32.4 \%$ \\
\hline Net income & & 640 & 496 & $29.0 \%$ \\
\hline [\% of net sales] & & $3.8 \%$ & $3.4 \%$ & $0.4 \mathrm{pp}$ \\
\hline Net income attributable to shareholders & & 634 & 490 & $29.3 \%$ \\
\hline [\% of net sales] & & $3.7 \%$ & $3.4 \%$ & $0.4 \mathrm{pp}$ \\
\hline Net income attributable to non-controlling interests & & 6 & 6 & $0.5 \%$ \\
\hline Basic earnings per share from continuing operations (in $€$ ) & 35 & 3.37 & 2.67 & $26.2 \%$ \\
\hline Diluted earnings per share from continuing operations (in €) & 35 & 3.37 & 2.67 & $26.2 \%$ \\
\hline $\begin{array}{l}\text { Basic earnings per share from continuing and discontinued operations } \\
\text { (in €) }\end{array}$ & 35 & 3.15 & 2.35 & $34.0 \%$ \\
\hline $\begin{array}{l}\text { Diluted earnings per share from continuing and discontinued operations } \\
\text { (in €) }\end{array}$ & 35 & 3.15 & 2.35 & $34.0 \%$ \\
\hline
\end{tabular}

Source: $h$ ttp://www.adidas-group.com/media/filer_public/e9/73/e973acf3-f889-43e5-b3c0-bc870d53b964/2015_gb_en.pdf

\begin{tabular}{lcc}
\hline & Puma (2015) & Adidas (2015) \\
\hline EBIT (millions $€$ ) & 96.3 & 1059 \\
\hline interest (millions $€$ ) & 11.2 & 21 \\
\hline EBT (millions $€$ ) & 85 & 1039 \\
\hline net profit (millions $€$ ) & 61.7 & 640 \\
\hline net profit/total sale (\%) & 1.82 & 3.78 \\
\hline EBIT/total sale $(\%)$ & 2.84 & 6.26 \\
\hline EBIT/interest & 8.6 & 50.43
\end{tabular}

Table 1. Comparative financial data of the companies in 2015

Source: Author 


\begin{tabular}{lcc}
\hline & Puma (2014) & Adidas (2014) \\
\hline EBIT(millions $€$ ) & 128.0 & 883 \\
\hline interest(millions $€$ ) & 6.2 & 48 \\
\hline EBT(millions $€$ ) & 121.8 & 835 \\
\hline net profit (millions $€)$ & 84.8 & 496 \\
\hline net profit/total sale $(\%)$ & 2.85 & 3.41 \\
\hline EBIT/total sale $(\%)$ & 4.31 & 6.08 \\
\hline EBIT/interest & 20.65 & 18.4 \\
\hline
\end{tabular}

Table 2. Comparative financial data of the companies in 2014

Source: Author

\section{UTICAJ ODREĐENIH PSIHOLOŠKIH FAKTORA INVESTITORA I MENADŽERA NA STRUKTURU KAPITALA}

Rezime:

Psihologija predstavlja osnovni uslov nastanka disciplina kao što su bihejvioralne finansije i bihejvioralna ekonomija. Ona je doprinela boljem razumevanju ponašanja ekonomskih aktera pod uslovima rizika koji proističu iz nesavršenosti kognitivnih sposobnosti ljudskih bića. Samim tim došlo se do zaključka da je potrebno menjati ekonomske modele zasnovane na matematičkim zakonitostima u korist deskriptivnih modela koji uvažavaju ograničene kognitivne sposobnosti ljudskog uma. Najčešće odluke koje se izučavaju u oblasti bihejvioralnih finansija jesu odluke o strukturi kapitala kompanija. Metodologija u ovom radu se zasniva na pristupu neto operativnog prihoda. Ovim pristupom se analizir afinansijska sekcija bilansa uspeha, koja se odnosi na finansijske troškove kompanija. Za finansijske troškove se pretpostavlja da su fiksni, čime se determiniše tačka indiferencije finansiranja, koja je posledica korišćenja finansijskog leveridža. Osnovni zadatak ovog rada jeste da se kroz dve studije slučaja komparativne analize bilansa uspeha kompanija Puma i Adidas determiniše uticaj psiholoških faktora na strukturu kapitala i nivo zaduženosti, koji će posledično da deluju na dostizanje tačke indiferencije finansiranja kao i na profitabilnost kompanija. Stoga, moguće je izvesti zaključak da psihologija donosilaca finansijskih odluka može da utiče na odluke o strukturi kapitala, što može da bude predmet daljih istraživanja.

Ključne reči:

pristrasnosti, lična uverenja, struktura kapitala, finansijski leveridž, beta koeficijent 